\title{
Do Bats use Scent Cues from Guano and Urine to Find Roosts?
}

\author{
Bridget K. G. Brown* and Gerald G. Carter
}

Department of Evolution, Ecology and Organismal Biology, The Ohio State University

*Corresponding author (Email: brown.6531@osu.edu)

Citation - Brown, B. K. G., \& Carter, G. G. (2022). Do bats use scent cues from guano and urine to find roosts? Animal Behavior and Cognition, 9(1), 106-118. https://doi.org/10.26451/abc.09.01.09.2022

\begin{abstract}
Selection of habitat is a key determinant of reproductive success, and the process of finding and choosing these sites is often influenced by the presence of conspecifics. Many bats frequently switch roosts, and some bats repeatedly find new roosts. To find roosts with conspecifics or group members, bats can use social cues. However, most research on how bats use social cues for roost-finding has focused on acoustic cues. Here, we review and discuss the evidence for bat roost selection using scent cues from guano and urine stains, which are present at most bat roosts. We outline reasons why bats might, or might not, use scent in roost detection and selection, and we review evidence on the possible use of guano and urine in roost-finding from eight studies with 12 bat species (across four families). Overall, the sparse evidence that exists indicates that scent cues from guano and urine are not a strong and consistent lure in the species and situations that were tested. Most studies had unclear results or found no effect. Two of the eight studies found weak experimental evidence for bats using guano or urine to select a roosting site. Even if guano and urine can indicate the presence of bats at a roost, it is possible that the resulting olfactory cues do not contain sufficient social information to be used in roost selection, in contrast to olfactory cues from scent marking. Studies of how bats use sensory cues beyond sound could contribute to a better understanding of bat social behavior and roosting ecology.
\end{abstract}

Keywords - Bats, Roosting ecology, Sensory ecology, Olfaction

An animal's choice of habitat can increase reproductive success through better access to resources or mates. In bats, choosing an ideal roost can provide a female with multiple benefits: a refuge from weather (Lausen \& Barclay, 2006), a reduced risk of predation (Lima \& O'Keefe, 2013), associations with other females that aggregate for warmth to raise young (Kunz \& Lumsden, 2003), and social information about resources like the location of foraging grounds or alternative roosts (Kerth \& Reckardt, 2003; Kerth et al., 2006; Safi \& Kerth, 2003; Wilkinson, 1992). For males, roosts provide access to females during the breeding season and can be defended in attempts to monopolize access to female groups (Dechmann et al., 2007; Heckel \& von Helverson, 2002). Because ideal roosts are limited, and each bat species seeks certain optimal roost characteristics (Kunz \& Lumsden, 2003; Kunz \& Pierson, 1994), bats often find or choose roosts using social cues, which convey the presence of conspecifics (Kerth, 2008).

Research on how bats use social cues in roost selection has predominantly focused on acoustic cues from echolocation and social calls (Chaverri et al., 2018). For example, Spix's disc-winged bats (Thyroptera tricolor) roost as small groups in ephemeral roosts (large, unfurled leaves), each group moves to a new roost daily, and group members coordinate their roost selection by exchanging distinctive contact calls (Chaverri et al., 2010, 2012). In several other bat species, individuals produce or use social calls when entering roosts (e.g., evening bats (Nycticeius humeralis, Wilkinson, 1992); Bechstein's bats (Myotis bechsteinii, Schöner et al., 2010); Natterer's bats (M. nattereri, Schöner et al., 2010); pallid bats (Antrozous 
pallidus, Arnold \& Wilkinson, 2011), and common noctules (Nyctalus noctula, Furmankiewicz et al., 2011)) and/or they use high-amplitude echolocation calls from conspecifics to locate roosts more efficiently (e.g., common noctules and Daubenton's bat (M. daubentonii, Ruczyński \& Kalko, 2007, Ruczyński et al., 2009)).

Far less is known about whether bats use scent cues to locate potential roosts, despite olfaction being an important sensory modality for almost all terrestrial mammals (Hayden et al., 2010). In this review, we discuss some reasons that bats would, or would not, use scent cues in habitat selection. We focus on studies testing the use of inadvertent cues from guano and urine because these scents are present at most occupied roosts, and anecdotal reports suggest these cues might be used by bats in roost selection. For example, some people have applied guano to artificial roost boxes to increase the chance of occupancy (Murphy, 1993; Ober, 2008). If guano staining was an effective olfactory lure for artificial bat roosts, this would be a helpful tool for bat management and conservation. Although one can buy chemical lures for bat houses based on distinct odors present in some bat roosts (Nielsen et al., 2006), there is no clear evidence of the effectiveness of any olfactory lure. More generally, a better understanding of the use of scent cues for roost-finding in bats can provide insights linking roosting ecology, social behavior, and sensory ecology in bats.

\section{Olfaction in Bats}

To assess the capacity of bats to use scent in roost selection, it is useful to review the basic structures for perceiving odors. In mammals, the key olfactory structures are the main olfactory system and the accessory olfactory system (AOS), which can include the vomeronasal organ (VNO) and the accessory olfactory bulb (AOB). Greater complexity of the epithelial structures in these systems can increase the amount of surface area, allowing for greater absorption of odorant molecules (Hecker et al., 2019). The vomeronasal system plays a large part in assessment of chemical cues involved in social behaviors such as mate attraction (Kelliher, 2007).

Nocturnal mammals tend to have larger olfactory structures (Barton et al., 1995) compared to other terrestrial mammals, but most bats have reduced olfactory systems, such as a reduced VNO, a reduced AOB, or the complete loss of one or both of these structures (Hecker et al., 2019). The exception is that an intact VNO and AOB exists in most, or all, species within two of 20 sampled families of bats (Phyllostomidae and Miniopteridae) and in the genus Pteronotus in the family Mormoopidae (Yohe \& Dávalos, 2018; Zhao et al., 2011). However, many bat species (e.g., most bats in the family Pteropodidae and Hipposideridae) still have not had their accessory olfactory structures examined (Zhao et al., 2011). Along with reductions in olfactory structures, most bat lineages have lost protein-coding genes - such as Trpc2 and S100z-linked to pheromone perception (Hecker et al., 2019; Yohe et al., 2017, 2019). Since many species of bats exhibit behaviors that involve pheromones, it is possible that the main olfactory system in bats incorporates the functions of these accessory systems (Yohe et al., 2017).

Diet plays an important role in the evolution of mammalian olfactory systems (Barton et al., 1995; Brokaw \& Smotherman, 2020; Eiting et al., 2014). Phyllostomid bats have the most diverse diet among the bat families (with both generalist omnivores and specialists on insects, fruit, nectar, blood, or small vertebrates), and of those studied to date, all but two phyllostomid species (Brachyphylla cavernarum and Choeroniscus godmani) have maintained all parts of their ancestral olfactory system. In contrast, in 18 of the other bat families, the sampled species have lost parts of these structures (Cooper \& Bhatnagar, 1976; Frahm \& Bhatnagar, 1980; Schmidt, 1985; Yohe et al., 2017; Yohe \& Dávalos, 2018; Zhao et al., 2011). For example, the vespertilionid bats are primarily composed of insectivores that probably rely less on scent, and 11 of 13 sampled vespertilionid species have lost both the VNO and AOB (Bhatnagar \& Kallen, 1974; Cooper \& Bhatnagar, 1976; Wible \& Bhatnagar, 1996; Yohe \& Dávalos, 2018). The loss of the AOS in so many bat lineages may be due to ecological differences, but the specific factors are not well understood (Yohe et al., 2017). 
Due to the strong link in other mammals between the vomeronasal system and the processing of social cues, bats with more developed VNOs and AOBs are expected to more frequently use olfaction during social interactions (Hecker et al., 2019). However, the relative roles of social and ecological factors as selective pressures are difficult to disentangle because (1) the main olfactory system in bats might coopt functions of the vomeronasal system, (2) there is a paucity of data on olfaction-based social communication in bats, and (3) social and ecological predictors can be statistically confounded. To take one example, the common vampire bat has a well-developed vomeronasal organ, one of the largest relative AOBs recorded in bats, and the most V1rs (Vomeronasal type-1 receptors) recorded to date (Yohe et al., 2019). As one might predict, this species is exceptional in its social complexity (Carter \& Leffer, 2015; Wilkinson et al., 2016), but it also appears to use olfaction to find its hosts, which include a large diversity of species (Bahlman \& Kelt, 2007; Carter et al., 2020), so it is unclear whether vampire bats evolved enhanced olfaction for social recognition, host recognition, or both.

\section{Reasons Why Bats Might or Might Not Use Scent to Choose Roosts}

Roost choice by bats involves multiple sensory cues (Hernández-Montero et al., 2020; Kerth, 2008; Ruczyński \& Kalko, 2007; Ruczyński et al., 2009), and there are several reasons why we might expect roost-finding bats to use scent-based social cues alongside other social cues. First, bats use scent in other contexts, such as social recognition, foraging, and mate selection (Bloss et al., 2002; Bouchard, 2001; Chaverri et al., 2018; De Fanis \& Jones, 1995; Theis et al., 2016). Olfaction can be used in combination with spatial memory and other senses depending on proximity to the target (Gomes et al., 2016; McCracken, 1993). For example, when searching for their pup in a creche with potentially hundreds or thousands of other pups, Brazilian free-tailed bats (Tadarida brasiliensis) seem to use spatial memory and isolation calls to first locate the general area of their pup, and then use scent to identify their specific pup (Gustin \& McCracken, 1987). This multi-modal integration has also been shown in the lesser long-nosed bat (Leptonycteris yerbabuenae) when it uses both echolocation and olfaction to locate cactus flowers (Gonzalez-Terrazas et al., 2016). Similarly, fruit-eating bats are thought to rely on olfaction to locate a fruiting tree and then a combination of echolocation and olfaction to pick ripe fruit (Kalko et al., 1996; Korine et al., 2000). Within interior forests or other high-clutter areas where high-frequency calls do not transmit well (Martens, 1980), bats might use olfactory cues of an unfamiliar, large roost to travel to the general area and then use social calls as a beacon to find the roost entrance once they are closer.

A second reason that scent cues are potentially useful is that they persist over time, whereas sounds convey the presence of bats only at that moment. Scent cues might be important for finding roosts in the absence of conspecifics, as when temperate bats make seasonal movements to summer sites that are vacant at the end of winter, or when a bat comes across a roost that is unoccupied during the night because the occupants are foraging.

Third, scent cues at roosts can be used for social recognition. Bats often preferentially roost with certain individuals, even in colonies where individuals frequently switch roosts and group composition changes day to day (Kerth et al., 2011; Popa-Lisseanu et al., 2008; Rhodes, 2007; Wilkinson et al., 2016; Willis \& Brigham, 2004). Maintaining preferred social associations is particularly important for cooperative behavior in some phyllostomid bats (Carter et al., 2020; Wilkinson, 1984; Wilkinson \& Boughman, 1998). Chemicals collected from various scent glands contain information about individual identity, and scent profiles might also be distinctive at the colony level in some species (e.g., the Bechstein's bat (Safi \& Kerth, 2003) and the greater bulldog bat (Noctilio leporinus, Brooke \& Decker, 1996)). In the Bechstein's bat, chemical profiles were similar within haplotypes and groups, but these similarities were not driven by pairwise kinship, because mean within-colony relatedness was only 0.02 , and the scent profiles of mothers and adult daughters were not more similar than among other groupmates (Safi \& Kerth, 2003). Given that different colonies had distinct chemical profiles, and bats from the more chemically different colonies were more aggressive to each other, colony-level differences in chemical profiles might also predict the outcomes of between-colony social encounters (Safi \& Kerth, 2003). 
When given a choice to associate with scent samples, bats preferred the scent of familiar versus unfamiliar individuals in the Angolan free-tailed bat (Mops condylurus, Bouchard, 2001), little free-tailed bat (Chaerephon pumilus, Bouchard, 2001), common pipistrelle (Pipistrellus pipistrellus, Bartonicka et al., 2010; De Fanis \& Jones 1995), soprano pipistrelle (P. pygmaeus, Bartonicka et al., 2010), greater sacwinged bat (Saccopteryx bilineata, Voigt \& von Helverson, 1999), big brown bat (Eptesicus fuscus, Bloss et al., 2002), and Brazilian free-tailed bat (Englert \& Greene, 2009; Gustin \& McCracken, 1987; Loughry \& McCracken, 1991). Males also responded differently to female versus male scents in the common pipistrelle (Bartonicka et al., 2010), soprano pipistrelle (Bartonicka et al., 2010), little free-tailed bat (Bouchard, 2001) and Angolan free-tailed bat (Bouchard, 2001). In a study with Egyptian fruit bats (Rousettus aegyptiacus), the subject chose between an unfamiliar and a familiar bat placed into two chambers, and it was suggested that the choice was based on olfaction due to the absence of visual and acoustic cues (Mann et al., 2011). All of these studies suggest a level of individual recognition through scent cues.

Fourth, roost-finding bats might use scent cues because in some species male bats use glands to scent mark roost entrances (e.g., Pacific flying fox (Pteropus tonganus, Grant \& Bannack, 1999), the black flying foxes ( $P$. gouldii, Moulton, 1967; Nelson, 1965), gray-headed flying fox ( $P$. poliocephalus, Moulton, 1967; Nelson, 1965), greater sac-winged bat (Caspers et al., 2009), pale spear-nosed bat (Phyllostomus discolor, Höller \& Schmidt, 1996), and lesser sac-winged bat (S. leptura, Caspers et al., 2009). Females can recognize quite a few individual characteristics from this scent marking, such as age, sex, social status, and identity, that can help them select a mate (Muñoz-Romo et al., 2021). While the function of scentmarking in males is to increase mating opportunities by signaling to females or rival males, scent marks at the entrance of a roost could also act as a cue to whether that roost was occupied by familiar or unfamiliar conspecifics.

Fifth, even without scent marking, many entrances to bat roosts accumulate guano and urine that provide inadvertent olfactory cues. Large, occupied bat roosts can accumulate urine and guano over months or years. Predators and trained dogs can locate bat roosts using scent (Chambers et al., 2015; Threlfall et al., 2013). Some owners of occupied bat houses have recommended applying guano to artificial roost boxes to help attract bats to them (e.g., Murphy, 1993; Ober, 2008). Beyond serving as a cue for roost location, feces and urine can communicate important social information in many other mammals (Beynon \& Hurst, 2004; Delahay et al., 2000; Eppley et al., 2016; Ferkin \& Johnston, 1995; Heth et al., 1998; Hurst et al., 2001; Ramsay \& Giller, 1996). The use of these scent cues does not imply any adaptive trait for enhanced olfaction, because bats with a weak sense of olfaction could learn to associate the scent of guano and urine with the reward of finding a new roost site.

Finally, although bats that do not roost in groups may be less likely to use conspecific scent cues to choose roosts, they could also use scent cues to find previously occupied sites that are now empty. Cues of previous occupancy could indicate a suitable roost microclimate but also an increased risk of exposure to predators or parasites.

There are also several reasons why we might not expect bats to use scent to find roosts. As mentioned above, the reduction in the accessory mammalian olfactory systems may indicate less reliance on olfaction relative to other terrestrial mammals. Second, if the primary benefit of a roost is the presence of other bats, then olfaction may not be a useful cue because, unlike bat calls, odors do not convey the immediate presence of other bats, and an empty but scented roost could have degraded since it was last occupied. Third, not all bat roosts accumulate guano and urine. For example, for foliage-roosting bats (as opposed to cavity-roosting bats) there is often not a bottlenecked roost "entrance" where guano would accumulate. Fourth, scent cues would be most useful for bats that need to find new roosts (i.e., no use of spatial memory), but the species that most frequently switch to new roosts (e.g., leaf-roosting bats) may not occupy them long enough to leave large concentrations of guano and urine. Finally, the range at which a bat can perceive cues will clearly play a role in a bat's ability to locate new roosts (Ruczyński \& Barton, 2012), and in some contexts like open habitats, even strong scent cues might have a more limited detection 
range compared with echolocation or social calls. Although bats possess olfaction and could plausibly use scent cues in roost choice, other sensory cues might be more easily detected or more salient.

Table 1

Summary of Species Used in the Reviewed Studies

\begin{tabular}{|c|c|c|c|c|c|c|}
\hline Family & Species & Diet & $\begin{array}{l}\text { Colony } \\
\text { size }\end{array}$ & Roost Type & $\begin{array}{c}\text { Olfactory System } \\
{[5,11,21,23,26,27]}\end{array}$ & $\begin{array}{c}\text { Evidence of use of } \\
\text { olfaction }\end{array}$ \\
\hline Vespertilionidae & $\begin{array}{l}\text { Myotis } \\
\text { lucifugus }\end{array}$ & insects & $\begin{array}{c}\sim 10-1000 \\
\quad[13]\end{array}$ & $\begin{array}{c}\text { tree cavities, } \\
\text { artificial roosts } \\
{[13]}\end{array}$ & VNO and AOB absent & $\begin{array}{l}\text { weak evidence when } \\
\text { homing [17] }\end{array}$ \\
\hline Vespertilionidae & $\begin{array}{l}\text { Myotis } \\
\text { sodalis }\end{array}$ & insects & $\begin{array}{l}\sim 10-1000 \\
\quad[22]\end{array}$ & $\begin{array}{l}\text { tree cavities, } \\
\text { artificial roosts } \\
{[22]}\end{array}$ & $\begin{array}{c}\text { Unknown. The family } \\
\text { often has VNO and } \\
\text { AOB absent. }\end{array}$ & $\begin{array}{l}\text { weak evidence when } \\
\text { homing [17] }\end{array}$ \\
\hline Hipposideridae & $\begin{array}{l}\text { Hipposideros } \\
\text { speoris }\end{array}$ & insects & $\begin{array}{c}\sim 10-1000 \\
{[4]}\end{array}$ & $\begin{array}{l}\text { caves } \\
{[4,21]}\end{array}$ & $\begin{array}{l}\text { Unknown. The family } \\
\text { often has VNO present } \\
\text { and AOB absent. }\end{array}$ & $\begin{array}{l}\text { good evidence for } \\
\text { using urine to mark } \\
\text { roosts [21] }\end{array}$ \\
\hline Vespertilionidae & $\begin{array}{c}\text { Lasionycteris } \\
\text { noctivagans }\end{array}$ & insects & $\begin{array}{c}\text { solitary } \\
{[1]}\end{array}$ & $\begin{array}{c}\text { tree crevices } \\
{[1]}\end{array}$ & $\begin{array}{l}\text { Unknown. The family } \\
\text { often has VNO and } \\
\text { AOB absent. }\end{array}$ & no evidence [1] \\
\hline Vespertilionidae & $\begin{array}{l}\text { Nycticeius } \\
\text { humeralis }\end{array}$ & insects & $\begin{array}{c}\sim 10-1000 \\
\quad[24]\end{array}$ & $\begin{array}{c}\text { tree cavities } \\
{[16]}\end{array}$ & $\begin{array}{c}\text { Unknown. The family } \\
\text { often has VNO and } \\
\text { AOB absent. }\end{array}$ & no evidence [10] \\
\hline Vespertilionidae & $\begin{array}{l}\text { Nyctalus } \\
\text { noctula }\end{array}$ & insects & $\begin{array}{c}\sim 10-1000 \\
{[2,18]}\end{array}$ & $\begin{array}{c}\text { tree cavities, } \\
\text { artificial roosts } \\
{[2,18]}\end{array}$ & VNO and AOB absent & no evidence $[19,20]$ \\
\hline Vespertilionidae & $\begin{array}{l}\text { Plecotus } \\
\text { auritus }\end{array}$ & insects & $\begin{array}{c}\sim 10-1000 \\
{[9]}\end{array}$ & $\begin{array}{c}\text { tree cavities, } \\
\text { artificial roosts } \\
\text { [9] }\end{array}$ & $\begin{array}{c}\text { VNO present and well- } \\
\text { developed, AOB is } \\
\text { unknown }\end{array}$ & no evidence $[19,20]$ \\
\hline Vespertilionidae & $\begin{array}{c}\text { Myotis } \\
\text { daubentonii }\end{array}$ & insects & $\begin{array}{c}\sim 10-1000 \\
{[2]}\end{array}$ & $\begin{array}{c}\text { tree cavities, } \\
\text { artificial roosts } \\
{[2]}\end{array}$ & $\begin{array}{c}\text { Unknown. The family } \\
\text { often has VNO and } \\
\text { AOB absent. }\end{array}$ & no evidence $[19,20]$ \\
\hline Molossidae & $\begin{array}{c}\text { Tadarida } \\
\text { brasiliensis }\end{array}$ & insects & $\begin{array}{c}\sim 10-1000 \\
{[14]}\end{array}$ & $\begin{array}{c}\text { caves, } \\
\text { artificial roosts } \\
{[6,12]}\end{array}$ & $\begin{array}{c}\text { VNO absent, AOB is } \\
\text { unknown }\end{array}$ & $\begin{array}{c}\text { good evidence for use } \\
\text { of scent cues (but } \\
\text { unclear what kind) } \\
{[8,10]}\end{array}$ \\
\hline Phyllostomidae & $\begin{array}{l}\text { Desmodus } \\
\text { rotundus }\end{array}$ & blood & $\begin{array}{l}\sim 10-1000 \\
{[25]}\end{array}$ & $\begin{array}{l}\text { hollow trees } \\
\text { [25] }\end{array}$ & $\begin{array}{l}\text { VNO and AOB present } \\
\text { and well-developed }\end{array}$ & $\begin{array}{l}\text { weak possible } \\
\text { evidence for use of } \\
\text { guano/urine in one } \\
\text { context [3] }\end{array}$ \\
\hline Vespertilionidae & $\begin{array}{l}\text { Eptesicus } \\
\text { fuscus }\end{array}$ & insects & $\begin{array}{c}\sim 10-1000 \\
{[15]}\end{array}$ & $\begin{array}{l}\text { tree cavities, } \\
\text { artificial roosts } \\
{[15]}\end{array}$ & VNO and AOB absent & no evidence [3] \\
\hline Molossidae & $\begin{array}{l}\text { Molossus } \\
\text { molossus }\end{array}$ & insects & $\begin{array}{c}\sim 10-100 \\
{[7]}\end{array}$ & $\begin{array}{c}\text { tree crevices, } \\
\text { artificial roosts } \\
\text { [7] }\end{array}$ & VNO and AOB absent & no evidence [3] \\
\hline
\end{tabular}

Note. 1. Barclay et al., 1988; 2. Boonman, 2006; 3. Brown et al., 2020; 4. Chinnasamy et al., 2011; 5. Cooper \& Bhatnagar, 1976; 6. Davis et al., 1962; 7. Dechmann et al., 2010; 8. Englert \& Greene, 2009; 9. Entwistle et al., 1997; 10. Finn, 1997; 11. Frahm \& Bhatnagar, 1980; 12. Fraze \& Wilkins, 1990; 13. Humphrey, 1966; 14. Keeley \& Keeley, 2004; 15. Kilgour et al., 2013; 16. Menzel et al., 2001; 17. Mueller, 1966; 18. Ruczyński \& Bogdanowicz, 2005; 19. Ruczyński \& Kalko, 2007; 20. Ruczyński et al., 2009; 21. Selvanayagam \& Marimuthu, 1984; 22. Silvis et al., 2014; 23. Wible \& Bhatnagar, 1976; 24. Wilkinson, 1992; 25. Wilkinson, 1984; 26. Yohe et al., 2017; 27. Zhao et al., 2011 
To assess evidence for and against these arguments, we conducted a literature review, using combinations of the search terms: bats, olfaction, scent, sensory ecology, roost, roosting ecology, olfactory bulb, recognition, homing, latrines, habitat selection, mammals, and habitat. We found 119 papers on olfaction, sensory ecology, and roosting ecology in bats. Below, in chronological order, we focus on the eight studies (with 12 species from four different families) with data that could address whether bats used guano and urine cues in roost selection (Barclay et al., 1988; Brown et al., 2020; Englert \& Greene, 2009; Finn, 1997; Mueller, 1966; Ruczyński \& Kalko, 2007; Ruczyński et al., 2009; Selvanayagam \& Marimuthu, 1984). For each species in these studies, we also summarized information about diet, social organization, roost type, and olfactory system (Table 1).

\section{Studies on the Use of Guano and Urine Scent in Roost Selection}

To test the importance of olfaction in the homing ability of bats, Mueller (1966) covered the nares of 35 little brown bats (M. lucifugus) and released 10 of these treated bats at a distance of $10 \mathrm{~km}$ from their hibernaculum, and another 25 treated bats at a distance of $32 \mathrm{~km}$. As a control group, he also released 25 untreated bats at each distance. Bats were marked with paint to distinguish between treatment groups. He repeated this study with Indiana bats (M. sodalis) by releasing 100 bats with their nares covered and 100 control bats at a site $32.2 \mathrm{~km}$ from their hibernacula. He did not analyze these data but argued that bats were at least capable of returning to a hibernaculum without the use of scent. A contingency test of the data (Chisquare test with Yates Correction), however, finds evidence that bats with covered nares were less likely to return to their roost at $32 \mathrm{~km}$. When little brown bats were released at a distance of $10 \mathrm{~km}$, there was no clear treatment effect (13 of 25 control bats returned, 3 of 10 treated bats returned with nares covered, and 5 more treated bats returned after removing the treatment from their nares). When released at a distance of $32 \mathrm{~km}$, none of the 25 treated bats returned with nares covered (six returned with uncovered nares), whereas 16 of the 25 control bats returned $\left(\mathrm{X}^{2}(\mathrm{~N}=44, \mathrm{df}=1)=11.6, p<.001\right)$. A similar pattern was found with Indiana bats released at $32 \mathrm{~km}$ : only four of the 100 treated bats returned with nares covered (and 18 returned with uncovered nares), whereas 18 of the 100 control bats returned $\left(\left(\mathrm{X}^{2}(\mathrm{~N}=182, \mathrm{df}=1)=6.1, p=\right.\right.$ .01). These results are consistent with an effect of olfaction on homing, but other explanations are also possible, such as that covering the nares affected survival, echolocation, or flight performance.

It is implausible that homing bats rely entirely on olfaction when locating hibernacula because they travel long distances, up to $500 \mathrm{~km}$ (Klüg-Baerwald et al., 2017; Norquay et al., 2013), but olfaction could aid in navigation. According to the empirically-supported olfactory navigation hypothesis (Wallraff, 2004), birds, such as homing pigeons, exploit natural odors across the landscape to aid their navigation (Gagliardo et al., 2011; Papi et al., 1973; Wallraff, 2004). While little brown bats do not have a VNO or AOB, they may still process and recognize certain scent cues close to their hibernaculum through their main olfactory system (Table 1). The results from Mueller (1966) are consistent with this hypothesis, but compared to birds, virtually nothing is known about the use of scent cues in homing by bats.

Selvanayagam and Marimuthu (1984) tested the impact of removing scent cues on the roosting and territorial behavior of the group-roosting Schneider's leaf-nosed bats (Hipposideros speoris). After marking 40 bats and observing them returning to their roosting locations in a cave, the authors noticed that males often sniffed the substrate near their previous roosting position. To determine if bats were indeed using scent to choose their roosting positions, the researchers washed the cave walls at these spots. Normally, it took bats an average of seven minutes to settle at roosting sites (12 observations from eight bats), but when the area was washed, it took them two to three hours (five observations from five bats). Further experiments in captivity showed that males and females were able to identify previous roosting locations, at least in part through sniffing behaviors. The bats also fought for the darkest roosting locations, and when the researchers moved the light around, the bats shifted their positions so the most dominant individuals were again in the darkest corners. Once the bats had chosen new positions, the males marked their area with urine. The bats appeared to discriminate their own urine from the urine of other individuals, because when urine from other males was placed in the roost site of a focal male, it would respond antagonistically upon its return and 
cover the mark with its own urine. Females did not mark roosting sites with their urine, but they sniffed at the roof of the cave in the wild and the cage in captivity, possibly using scent from neighbors to choose their roosting position. All these observations suggest that males use urine marks to advertise their territory and re-locate their roosting spots within a single cave. This indicates that these bats are likely able to process pheromones in the urine, possibly through their VNO, but it does not indicate how they initially find and select their roosting sites (Table 1).

Barclay et al. (1988) tested individual silver-haired bats (Lasionycteris noctivagans) in a flight cage with two roosts that were identical except that one had a conspecific bat placed inside it for at least $24 \mathrm{hr}$ before the trial. Eleven bats selected the scented roost in 12 of 21 trials. Although silver-haired bats typically roost in tree crevices that could become scented, an attraction to roosts with unfamiliar scent cues is not strongly expected because they do not normally roost with conspecifics (Barclay et al., 1988; Table 1).

Finn (1997) studied whether guano and urine could be used to attract bats, but the results were unclear. In 13 field trials, bats were trapped in a roost box where their scent was able to accumulate. Groups of Brazilian free-tailed bats (mean group size $=23$ bats, range $=6$ to 110 bats), and evening bats (mean group size $=4$ bats, range $=1$ to 9 bats), were each placed inside a roost box near an established roost at dawn, and most bats then stayed inside until sunset. After the bats left the roost box in the evening, no bats were observed there for the next two days. In a captive experiment, six groups of 14 to 16 bats (six trials, 79 Brazilian free-tailed bats and 10 evening bats) were each given the option of different roosts in a flight cage, including four plywood bat houses, two pine bark structures, three bricks with roost holes, and two scented roost sites. The scented sites contained a cotton rag with guano and urine from a small colony of evening bats and a nylon stocking tube (folded in such a way that a bat could crawl into the middle) filled with guano from a colony of Brazilian free-tailed bats. Roosting choices were recorded the next morning. In two different trials, one Brazilian free-tailed bat roosted on the nylon stocking. Without proper experimental control conditions for comparison, these observations are difficult to interpret.

Two experiments tested the sensory basis for selecting new roosts in three group-roosting vespertilionid species, the common noctule bat, brown long-eared bat, and Daubenton's bat, (Ruczyński \& Kalko, 2007; Ruczyński et al., 2009; see Table 1). These studies aimed to isolate and test how the success of locating new roosts was affected by sound (echolocation call playbacks), temperature (a heated roost), vision (presence of light), and scent (a cloth treated with some of the bat's feces placed into each bat's cage for 24-48 hr). In training trials, each bat was trained to find one of eight cavities drilled into a log by rewarding them with mealworms when they found a cavity. A bat was included in the study when it consistently found a cavity within six minutes. In each test trial, only one of the eight cavities contained the stimulus. Each subject (eight noctule bats, six long-eared bats, and nine Daubenton's bats) was tested eight times for each of the four stimuli ( 32 trials per bat). Researchers measured latency for a bat to locate cavities with or without the stimulus. For the scent treatment, bats did not locate the scented roosts more often or faster than unscented roosts, regardless of whether they circled the log in flight or landed on the log and crawled around. While the scent cues did not decrease search time for cavities, conspecific echolocation calls clearly did improve search times. In this study, the scent cue was from the subject itself, rather than the scent of a conspecific which would better represent a bat locating a new roost.

Englert and Greene (2009) collected scents by placing felt squares in roost pouches within two captive colonies of Brazilian free-tailed bats for five days. Individual bats $(N=20)$ chose between three roosting pouches: one with scent from the familiar colony, one with scent from the non-familiar colony, and a clean control pouch. Bats preferred roost pouches with the familiar scents over the other pouches. Although it is possible that the felt squares were marked with guano or urine, the source of olfactory cues used for roost choice is not clear.

Brown et al. (2020) investigated the use of conspecific guano and urine cues in the location of new roosts in three group-living bat species (vampire bats, Desmodus rotundus; velvety free-tailed bats, Molossus molossus; and big brown bats, Eptesicus fuscus; see Table 1). Eight experiments tested a range of situations, all of which offered individual bats the choice between a scented or unscented roosting location either in the field using roost boxes or in captivity using a dark chamber, a lit room with dark 
refuges, or a y-maze. First, five captive common vampire bats repeatedly chose scented tubes more often than unscented tubes, when escaping from light. However, in three other experiments, vampire bats $(N=$ 20,22, and 33) chose between scented and unscented roosting locations in a small chamber that was entirely dark, and there was no clear evidence of a bias under these conditions. There was also no evidence for attraction to guano and urine scent when 45 vampire bats were tested in a y-maze, although the same individuals were clearly attracted to playbacks of echolocation and social calls. Velvety free-tailed bats (N $=18$ ) also showed no clear preference for hanging on surfaces marked with guano and urine.

To test the effectiveness of a potential olfactory lure for attracting wild bats, Brown et al. (2020) also placed paired artificial roosts, one treated with guano and urine and one as a control, for one week at each of 16 sites in Panama and seven sites in Ohio, U.S.A., near existing and occupied artificial roosts. These roosts were monitored with acoustic detectors to determine when bats were visiting and what species were visiting. These field experiments failed to provide clear results because only one visit was recorded, at a scented box in Ohio. The artificial roosts were placed temporarily near existing roosts, so it is possible that sensory cues from the occupied natural roost overshadowed the cues from the artificial roosts, and since in most cases, the scent cues were from other sites, it is also possible that bats were repulsed by scents of unfamiliar conspecifics.

\section{Summary of the Evidence}

Taken together, what do these studies tell us? First, although bats clearly use scent in many contexts, the sparse evidence that exists suggests that the scent of guano and urine does not act as a dramatic olfactory beacon that lures bats towards roost locations to the same degree as bat calls can provide an acoustic lure (e.g., feeding buzzes, social calls, or even distress calls; Braun De Torrez et al., 2017; Carter et al., 2015; Gillam, 2007; Samoray et al., 2019). In fact, three of the studies that looked at the effect of guano and urine on roost location also looked at the effect of acoustic cues and found that while guano did not readily attract bats, acoustic cues had strong and clear effects on attracting bats to roosts (Brown et al., 2020; Ruczyński \& Kalko, 2007; Ruczyński et al., 2009). This finding is consistent with the hypothesis that scent cues are not as reliable of an indicator of the immediate presence of conspecifics or the current viability of a roost, when compared to the acoustic cues of bat calls.

There is still much uncertainty regarding if and how different bats use guano and urine or other scents in roost selection. Most of the studies we included were statistically underpowered with limitations in sampling or deficiencies in the experimental design. Bats might rely on scent cues from guano and urine only within specific contexts or motivational states, such as males searching for females, or young bats searching for conspecifics after dispersing into new areas. In the study by Selvanayagam and Marimuthu (1984), for instance, the male bats may have been using urine to locate their own roosting locations, to advertise their roosting locations to other bats, or both. Similarly, Brown et al. (2020) appeared to have detected a strong effect of guano and urine on roost selection when bats were seeking a dark refuge, but the effect was not detected in other experiments when the entire experimental arena was dark. Some scent cues clearly do influence roost selection (Englert \& Greene, 2009), but even if guano and urine is an indicator of the presence of bats at a roost, it is possible that these cues do not contain sufficient social information to be used in roost selection. While guano and urine are present at most bat roosts, scent signals, such as gland secretions, might play a larger role in roost location.

\section{Future Research and Further Questions}

The best evidence for an effect of urine on roost selection comes from a study that used a design that controls for the effects of spatial memory by testing the bats' reaction to the removal of the scent at a familiar location (Selvanayagam \& Marimuthu, 1984). Therefore, an experimental design that manipulates scent at a familiar location, rather than at new locations, seems like a promising approach for future experiments. For example, one approach would be to present a scented and unscented entrance to a roost in 
equal proximity to the familiar entrance which is now blocked and test which new entrance is used (Brown et al., 2020). Another approach would be to swap guano and urine scents that are familiar versus unfamiliar for a random half of bats trained to return to the same familiar roost and then to measure each bat's latency to enter the roost.

In some rodents (Böcskei et al., 1992; Hurst et al., 2001) and carnivores (Hradeck, 1985), social information, such as individual identity or genetic relatedness, is conveyed through major urinary proteins (Beynon \& Hurst, 2004; Zhou \& Rui, 2010). Therefore, it would be pertinent to identify the social information, if any, that is present in the guano or urine of bats. To test the perception of social information in guano or urine, bats could be tested in a y-maze where either the subject or the source of the sample varies by identity, sex, or reproductive status. To determine the persistence of chemical information over time, similar tests could be repeated with fresh and old (decayed) samples. Testing the production of social information, requires chemically analyzing samples (e.g., using gas-chromatography mass spectrometry) to identify the combinations of compounds encoding social information. Finally, the eight studies included in this review tested only four different bat families and only one known to have a well-developed main and accessory olfactory system. Behavioral data from more bat species is clearly needed to resolve the role of olfaction in the roosting and sensory ecology of bats.

\section{Acknowledgements}

We would like to thank Imran Razik, Ian Hamilton, and Rachelle Adams for their feedback during the writing of this manuscript. Work by G. Carter is supported by a grant from the National Science Foundation (Integrative Organismal Systems \#2015928).

Conflict of interest: The authors certify that they do not have any known conflict of interest with the subject matter discussed in this manuscript.

\section{References}

Arnold, B. D., \& Wilkinson, G. S. (2011). Individual specific contact calls of pallid bats (Antrozous pallidus) attract conspecifics at roosting sites. Behavioral Ecology and Sociobiology, 65(8), 1581-1593.

Bahlman, J. W., \& Kelt, D. A. (2007). Use of olfaction during prey location by the common vampire bat (Desmodus rotundus). Biotropica, 39(1), 147-149.

Barclay, R. M. R., Faure, P. A., \& Farr, D. R. (1988). Roosting behavior and roost selection by migrating silver-haired bats (Lasionycteris noctivagans). Journal of Mammalogy, 69(4), 821-825.

Barton, R. A., Purvis, A., \& Harvey, P. H. (1995). Evolutionary radiation of visual and olfactory brain systems in primates, bats and insectivores. Philosophical Transactions of the Royal Society of London. Series B: Biological Sciences, 348(1326), 381-392.

Bartonicka, T., Kanuch, P., Bímová, B., \& Bryja, J. (2010). Olfactory discrimination between two cryptic species of bats Pipistrellus pipistrellus and P. pygmaeus. Folia Zoologica, 59(3), 175-182.

Beynon, R. J., \& Hurst, J. L. (2004). Urinary proteins and the modulation of chemical scents in mice and rats. Peptides, 25(9), 1553-1563.

Bhatnagar, K. P., \& Kallen, F. C. (1974). Cribriform plate of ethmoid, olfactory bulb and olfactory acuity in forty species of bats. Journal of Morphology, 142(1), 71-124.

Bloss, J., Acree, T. E., Bloss, J. M., Hood, W. R., \& Kunz, T. H. (2002). Potential use of chemical cues for colonymate recognition in the big brown bat, Eptesicus fuscus. Journal of Chemical Ecology, 28(4), 819-834.

Böcskei, Z., Groom, C. R., Flower, D. R., Wright, C. E., Phillips, S. E. V., Cavaggioni, A., \& Findlay, J. B. C. (1992). Pheromone binding to two rodent urinary proteins revealed by X-ray crystallography. Nature, 360(6400), $186-188$.

Boonman, M. (2006). Roost selection by noctules (Nyctalus noctule) and Daubenton's bats (Myotis daubentonii). Journal of Zoology, 251(3), 385-389. 
Bouchard, S. (2001). Sex discrimination and roostmate recognition by olfactory cues in the African bats, Mops condylurus and Chaerephon pumilus (Chiroptera: Molossidae). Journal of Zoology, 254(1), 109-117.

Braun De Torrez, E. C., Samoray, S. T., Silas, K. A., Wallrichs, M. A., Gumbert, M. W., Ober, H. K., \& McCleery, R. A. (2017). Acoustic lure allows for capture of high-flying, endangered bat. Wildlife Society Bulletin, 41(2), 322-328.

Brokaw, A. F., \& Smotherman, M. (2020). Role of ecology in shaping external nasal morphology in bats and implications for olfactory tracking. PLoS One, 15(1), 1-22.

Brooke, A. P., \& Decker, D. M. (1996). Lipid compounds in secretions of fishing bat, Noctilio leporinus (Chiroptera: Noctilionidae). Journal of Chemical Ecology, 229(8), 1411-1428.

Brown, B. K. G., Leffer, L., Valverde, Y., Toshkova, N., Nystrom, J., Page, R. A., \& Carter, G. G. (2020). Do bats use guano and urine stains to find new roosts? Tests with three group-living bats. Royal Society Open Science, 7(9), 201055.

Carter, G., \& Leffer, L. (2015). Social grooming in bats: Are vampire bats exceptional? PLoS ONE, 10(10), e0138430.

Carter, G., Schoeppler, D., Manthey, M., Knörnschild, M., \& Denzinger, A. (2015). Distress calls of a fast-flying bat (Molossus molossus) provoke inspection flights but not cooperative mobbing. PLoS One, 10(9), e0136146.

Carter, G., Farine, D., Crisp, R., Vrtilek, J., \& Ripperger, S. (2020). Development of new food-sharing relationships in vampire bats. Current Biology, 30(7), 1275-1279.

Caspers, B. A., Schroeder, F. C., Franke, S., Streich, W. J., \& Voigt, C. C. (2009). Odour-based species recognition in two sympatric species of sac-winged bats (Saccopteryx bilineata, S. leptura): Combining chemical analyses, behavioural observations and odour preference tests. Behavioral Ecology and Sociobiology, 63(5), 741-749.

Chambers, C. L., Vojta, C. D., Mering, E. D., \& Davenport, B. (2015). Efficacy of scent-detection dogs for locating bat roosts in trees and snags: Using detection dogs to locate bat roosts. Wildlife Society Bulletin, 39(4), 780787.

Chaverri, G., Ancillotto, L., \& Russo, D. (2018). Social communication in bats: Communication in bats. Biological Reviews, 93(4), 1938-1954.

Chaverri, G., Gillam, E. H., \& Kunz, T. H. (2012). A call-and-response system facilitates group cohesion among discwinged bats. Behavioral Ecology, 24(2), 481-487.

Chaverri, G., Gillam, E. H., \& Vonhof, M. J. (2010). Social calls used by a leaf-roosting bat to signal location. Biology Letters, 6(4), 441-444.

Chinnasamy, L., Pitchamuthu, M., Swani Doss, P., Marimuthu, G., \& Rajan, K. E. (2011). Genetic diversity and population structure of leaf-nosed bat Hipposideros speoris (Chiroptera: Hipposideridae) in Indian subcontinent. African Journal of Biotechnology, 10(8), 1320-1328.

Cooper, J. G., \& Bhatnagar, K. P. (1976). Comparative anatomy of the vomeronasal organ complex in bats. Journal of Anatomy, 122(3), 571-601.

Davis, A., Herreid, C. F. II, \& Short, H. L. (1962). Mexican free-tailed bats in Texas. Ecological Monograms, 32, 311-346.

De Fanis, E., \& Jones, G. (1995). Post-natal growth, mother-young interactions and development of vocalizations in the vespertilionid bat Plecotus auritus. Journal of Zoology (London), 235, 85-97.

Dechmann, D. K. N., Kalko, E. K. V., \& Kerth, G. (2007). All-offspring dispersal in a tropical mammal with resource defense polygyny. Behavioral Ecology and Sociobiology, 61(8), 1219-1228.

Dechmann, D. K. N., Kranstauber, B., Gibbs, D., \& Wikelski, M. (2010). Group hunting - a reason for sociality in Molossid bats? PLoS ONE, 5(2), e9012.

Delahay, R. J., Brown, J. A., Mallinson, P. J., Spyvee, P. D., Handoll, D., Rogers, L. M., \& Cheeseman, C. L. (2000). The use of marked bait in studies of the territorial organization of the European Badger (Meles meles). Mammal Review, 30(2), 73-87.

Eiting, T. P., Smith, T. D., \& Dumont, E. R. (2014). Olfactory epithelium in the olfactory recess: A case study in new world leaf-nosed bats. The Anatomical Record, 297(11), 2105-2112.

Englert, A. C., \& Greene, M. J. (2009). Chemically-mediated roostmate recognition and roost selection by Brazilian free-tailed bats (Tadarida brasiliensis). PLoS ONE, 4(11), e 7781.

Entwistle, A. C., Racey, P. A., \& Speakman, J. R. (1997). Roost selection by the brown long-eared bat Plecotus auratus. Journal of Applied Ecology, 34, 399-408.

Eppley, T. M., Ganzhorn, J. U., \& Donati, G. (2016). Latrine behaviour as a multimodal communicatory signal station in wild lemurs: The case of Hapalemur meridionalis. Animal Behaviour, 111, 57-67. 
Ferkin, M. H., \& Johnston, R. E. (1995). Meadow voles, Microtus pennsylvanicus, use multiple sources of scent for sex recognition. Animal Behaviour, 49(1), 37-44.

Finn, L. S. (1997). Bat house use in central Florida, with emphasis on Nycticeius humeralis and Tadarida brasiliensis cynocephala [Unpublished doctoral dissertation]. University of Central Florida.

Frahm, H. D., \& Bhatnagar, K. W. P. (1980). Comparative morphology of the accessory olfactory bulb in bats. Journal of Anatomy, 103(2), 349-365.

Fraze, R. K., \& Wilkins, K. T. (1990). Patterns of use of man-made roosts by Tadarida brasiliensis mexicana in Texas. The Southwestern Naturalist, 35(3), 261.

Furmankiewicz, J., Ruczyński, I., Urban, R., \& Jones, G. (2011). Social calls provide tree-dwelling bats with information about the location of conspecifics at roosts. Ethology, 117(6), 480-489.

Gagliardo, A., Ioalè, P., Filannino, C., \& Wikelski, M. (2011). Homing pigeons only navigate in air with intact environmental odours: A test of the olfactory activation hypothesis with GPS data loggers. PLoS ONE, 6(8), e22385.

Gillam, E. H. (2007). Eavesdropping by bats on the feeding buzzes of conspecifics. Journal of Zoology, 85(7), 795801.

Gomes, D. G. E., Halfwerk, W., Taylor, R. C., Ryan, M. J., \& Page, R. A. (2016). Multimodal weighting difference by bats and their prey: Probing natural selection pressures on sexually selected traits. Animal Behaviour, 134(12), 99-102.

Gonzalez-Terrazas, T. P., Martel, C., Milet-Pinheiro, P., Ayasse, M., Kalko, E. K. V., \& Tschapka M. (2016). Finding flowers in the dark: Nectar-feeding bats integrate olfaction and echolocation while foraging for nectar. Royal Society Open Science, 3(8), 160199.

Grant, G. S., \& Bannack, S. A. (1999). Harem structure and reproductive behaviour of Pteropus tonganus in American Samoa. Australian Mammalogy, 21(1), 111-120.

Gustin, M. K., \& McCracken, G. F. (1987). Scent recognition in the Mexican free-tailed bat, Tadarida brasiliensis mexicana. Animal Behaviour, 35(1), 13-19.

Hayden, S., Bekaert, M., Crider, T. A., Mariani, S., Murphy, W. J., \& Teeling, E. C. (2010). Ecological adaptation determines functional mammalian olfactory subgenomes. Genome Research, 20, 1-9.

Heckel, G., \& von Helverson, O. (2002). Male tactics and reproductive success in the harem polygynous bat Saccopteryx bilineata. Behavioral Ecology, 13(6), 750-756.

Hecker, N., Lächele, U., Stuckas, H., Giere, P., \& Hiller, M. (2019). Convergent vomeronasal system reduction in mammals coincides with convergent losses of calcium signalling and odorant-degrading genes. Molecular Ecology, 28(16), 3656-3668.

Hernández-Montero, J. R., Reusch C., Simon, R., Schöner, R., \& Kerth G. (2020). Free-ranging bats combine three different cognitive processes for roost localization. Oecologia, 192(4), 979-988.

Heth, G., Todrank, J., \& Johnston, R. E. (1998). Kin recognition in golden hamsters: Evidence for phenotype matching. Animal Behaviour, 56(2), 409-417.

Höller, P., \& Schmidt, U. (1996). The orientation behaviour of the lesser spearnosed bat, Phyllostomus discolor (Chiroptera) in a model roost: Concurrence of visual, echoacoustical and endogenous spatial information. Journal of Comparative Physiology A, 179(2), 245-255.

Hradeck, P. (1985). Possible pheromonal regulation of reproduction in wild carnivores. Journal of Chemical Ecology, 11(2), 241-250.

Humphrey, S. R. (1966). Population ecology of the little brown bat, Myotis lucifugus, in Indiana and north-central Kentucky [Unpublished doctoral dissertation]. Earlham College.

Hurst, J. L., Payne, C. E., Nevison, C. M., Marie, A. D., Humphries, R. E., Robertson, D. H. L., Cavaggioni, A., \& Beynon, R. J. (2001). Individual recognition in mice mediated by major urinary proteins. Nature, 414(6864), 631-634.

Keeley, A. T. H., \& Keeley, B. W. (2004). The mating system of Tadarida brasiliensis in a large highway bridge colony. Journal of Mammalogy, 85(1), 113-119.

Kalko, E. K. V., Herre, E. A., \& Handley, C. O. Jr. (1996). Relation of fig fruit characteristics to fruit-eating bats in the new and old-world tropics. Journal of Biogeography, 23(4), 565-576.

Kelliher, K. R. (2007). The combined role of the main olfactory and vomeronasal systems in social communication in mammals. Hormones and Behavior, 52(5), 561-570.

Kerth, G. (2008). Causes and consequences of sociality in bats. BioScience, 58(8), 737-746.

Kerth, G., \& Reckardt, K. (2003). Information transfer about roosts in female Bechstein's bats: An experimental field study. Proceedings of the Royal Society of London, Series B: Biological Sciences, 270(1514), 511-515. 
Kerth, G., Ebert, C., \& Schmidtke, C. (2006). Group decision making in fission-fusion societies: Evidence from two field experiments in Bechstein's bats. Proceedings of the Royal Society B, 273(1602), 2785-2790.

Kerth, G., Perony, N., \& Schweitzer, F. (2011). Bats are able to maintain long-term social relationships despite the high fission-fusion dynamics of their groups. Proceedings of the Royal Society B: Biological Sciences, 278(1719), 2761-2767.

Kilgour, R. J., Faure, P. A., \& Brigham, R. M. (2013). Evidence of social preferences in big brown bats (Eptesicus fuscus). Canadian Journal of Zoology, 91(10), 756-760.

Klüg-Baerwald, B. J., Lausen, C. L., Willis, C. K. R., \& Brigham, R. M. (2017). Home is where you hang your bat: Winter roost selection by prairie-living big brown bats. Journal of Mammalogy, 98(3), 752-760.

Korine, C., Kalko, E. K. V., \& Herre E. A. (2000). Fruit characteristics and factors affecting fruit removal in Panamanian community of strangler figs. Oecologia, 123(4), 560-568.

Kunz, T. H., \& Pierson, E. D. (1994). Bats of the world: An introduction. In R. M. Nowak (Ed.), Walker's Bats of the World (pp. 1-47). Johns Hopkins University Press.

Kunz, T. H., \& Lumsden, L. F. (2003). Ecology of cavity and foliage roosting bats. In T. H. Kunz \& M. B. Fenton (Eds.), Bat Ecology (pp. 3-89). University of Chicago Press.

Lausen, C. L., \& Barclay, R. M. R. (2006). Benefits of living in a building: Big brown bats (Eptesicus fuscus) in rocks versus buildings. Journal of Mammalogy, 87(2), 362-370.

Lima, S. L., \& O'Keefe, J. M. (2013). Do predators influence the behaviour of bats? Bats and predators. Biological Reviews, 88(3), 626-644.

Loughry, W. J., \& McCracken, G. F. (1991). Factors influencing female-pup scent recognition in Mexican free-tailed bats. Journal of Mammalogy, 72(3), 624-626.

Mann, O., Lieberman, V., Köhler, A., Korine, C., Hedworth, H. E., \& Voigt-Heucke, S. L. (2011). Finding your friends at densely populated roosting places: Male Egyptian fruit bats (Rousettus aegyptiacus) distinguish between familiar and unfamiliar conspecifics. Acta Chiropterologica, 13(2), 411-417.

Martens, M. J. M. (1980). Foliage as a low-pass filter: Experiments with model forests in an anechoic chamber. Journal of the Acoustical Society of America, 67, 66-72.

McCracken, G. F. (1993). Locational memory and female-pup reunions in Mexican free-tailed bat maternity colonies. Animal Behaviour,45(4), 811-813.

Menzel, M. A., Carter, T. C., Ford, W. M., \& Chapman, B. R. (2001). Tree-roost characteristics of subadult and female adult evening bats (Nycticeius humeralis) in the upper coastal plains of South Carolina. The American Midland Naturalist, 145(1), 112-119.

Moulton, D. G. (1967). Olfaction in mammals. American Zoologist, 7(3), 421-429.

Mueller, H. C. (1966). Homing and distance-orientation in bats [Unpublished doctoral dissertation]. University of Wisconsin.

Muñoz-Romo, M., Page, R. A., \& Kunz, T. H. (2021). Redefining the study of sexual dimorphism in bats: Following the odour trail. Mammal Review, 51(2021), 155-177.

Murphy, M. (1993). Bats: A farmer's best friend. Bats Magazine, 11(1).

Nelson, J. E. (1965). Behaviour of Australian pteropodidae (Megachiroptera). Animal Behaviour, 13(4), 544-557.

Nielsen, L. T., Eaton, D. K., Wright, D. W., \& Schmidt-French, B. (2006). Characteristic odors of Tadarida brasiliensis mexicana chiroptera: Molossidae. Journal of Cave and Karst Studies, 68(1), 27-31.

Norquay, K. J. O., Martinez-Nuñez, F., Dubois, J. E., Monson, K. M., \& Willis, C. K. R. (2013). Long-distance movements of little brown bats (Myotis lucifugus). Journal of Mammalogy, 94(2), 506-515.

Ober, H. K. (2008). Effective bat houses for Florida [Unpublished doctoral dissertation]. University of Florida Institute of Food and Agricultural Sciences.

Papi, F., Fiore, L., Fiaschi, V., \& Benvenuti, S. (1973). An experiment for testing the hypothesis of olfactory navigation of homing pigeons. Journal of Comparative Physiology, 83, 93-102.

Popa-Lisseanu, A. G., Bontadina, F., Mora, O., \& Ibáñez C. (2008). Highly structured fission-fusion societies in an aerial-hawking carnivorous bat. Animal Behaviour, 75(2), 471-482.

Ramsay, N. F., \& Giller, P. S. (1996). Scent-marking in ring-tailed lemurs: Responses to the introduction of "foreign" scent in the home range. Primates, 37, 13-23.

Rhodes, M. (2007). Roost fidelity and fission-fusion dynamics of white-striped free-tailed bats (Tadarida australis). Journal of Mammalogy, 88(5), 1252-1260.

Ruczyński, I., \& Barton K. A. (2012). Modelling sensory limitation: The role of tree selection, memory and information transfer in bats' roost searching strategies. PLOS ONE, 7(9), e44897. 
Ruczyński, I., \& Bogdanowicz, W. (2005). Roost cavity selection by Nyctalus noctule and N. leisleri (Vestpertilionidae, Chiroptera) in Bialowieza Primeval Forest, Eastern Poland. Journal of Mammalogy, 86(5), 921-930.

Ruczyński, I., \& Kalko, E. K. V. (2007). The sensory basis of roost finding in a forest bat, Nyctalus noctula. Journal of Experimental Biology, 210(20), 3607-3615.

Ruczyński, I., Kalko, E. K. V., \& Siemers, B. M. (2009). Calls in the forest: A comparative approach to how bats find tree cavities. Ethology, 115(2), 167-177.

Safi, K., \& Kerth, G. (2003). Secretions of the interaural gland contain information about individuality and colony membership in the Bechstein's bat. Animal Behaviour, 65(2), 363-369.

Samoray, S. T., Gumbert, M. W., Robey, P. L., Janos, G. A., \& Borthwick, R. R. (2019). Effectiveness of acoustic lures for increasing Indiana bat captures in mist-nets. Journal of Fish and Wildlife Management, 10(1), 206212.

Schmidt, U. (1985). The bats: Order Chiroptera. In R. E. Brown \& D. W. MacDonald (Eds.), Social odours in mammals (pp. 217-234). Clarendon Press.

Schöner, C. R., Schöner, M. G., \& Kerth, G. (2010). Similar is not the same: Social calls of conspecifics are more effective in attracting wild bats to day roosts than those of other bat species. Behavioral Ecology and Sociobiology, 64(12), 2053-2063.

Selvanayagam, P. F. L., \& Marimuthu, G. (1984). Spatial organization of roosting in the insectivorous tropical bat, Hipposideros speoris. Behavioural Processes, 9(2), 113-121.

Silvis, A., Kniowski, A. B., Gehrt, S. D., Ford, W. M. (2014). Roosting and foraging social structure of the endangered Indiana bat (Myotis sodalis). PLoS ONE, 9(5), e96937.

Theis, W., Kalko, E., \& Schnitzler, H. (2016). The roles of echolocation and olfaction in two neotropical fruit-eating bats, Carollia perspicillata and C. castanea, feeding on piper. Behavioral Ecology and Sociobiology, 42(6), 397-409.

Threlfall, C., Law, B., \& Banks, P. B. (2013). Odour cues influence predation risk at artificial bat roosts in urban bushland. Biology Letters, 9, 20121144.

Voigt, C. C., \& von Helversen, O. (1999). Storage and display of odour by male Saccopteryx bilineata (Chiroptera, Emballonuridae). Behavioral Ecology and Sociobiology, 47(1), 29-40.

Wallraff, H. G. (2004). Avian olfactory navigation: Its empirical foundation and conceptual state. Animal Behaviour, 67(2), 189-204.

Wible, J. R., \& Bhatnagar, K. P. (1996). Chiropteran vomeronasal complex and the interfamilial relationships of bats. Journal of Mammalian Evolution, 3, 285-314.

Wilkinson, G. S. (1984). Reciprocal food sharing in the vampire bat. Nature, 308, 181-184.

Wilkinson, G. S. (1992). Information transfer at evening bat colonies. Animal Behaviour, 44(3), 501-518.

Wilkinson, G. S., \& Boughman W. (1998). Social calls coordinate foraging in greater spear-nosed bats. Animal Behaviour, 55(2), 337-350.

Wilkinson, G. S., Carter, G. G., Bohn, K. M., \& Adams, D. M. (2016). Non-kin cooperation in bats. Philosophical Transactions of the Royal Society B: Biological Sciences, 371(1687), 20150095.

Willis, C. K., \& Brigham, R. M. (2004). Roost switching, roost sharing and social cohesion: Forest-dwelling big brown bats, Eptesicus fuscus, conform to the fission-fusion model. Animal Behaviour, 68(3), 495-505.

Yohe, L. R., Abubakar, R., Giordano, C., Dumont, E., Sears, K. E., Rossiter, S. J., \& Dávalos, L. M. (2017). Trpc2 pseudogenization dynamics in bats reveal ancestral vomeronasal signaling, then pervasive loss: $\operatorname{Trpc} 2$ infers loss, not gain, of bat vomerolfaction. Evolution, 71(4), 923-935.

Yohe, L. R., \& Dávalos, L. M. (2018). Strength of selection on the Trpc2 gene predicts accessory olfactory bulb form in bat vomeronasal evolution. Biological Journal of the Linnean Society, 123, 796-804.

Yohe, L. R., Davies, K. T. J., Rossiter, S. J., \& Dávalos, L. M. (2019). Expressed vomeronasal type-1 receptors (V1rs) in bats uncover conserved sequences underlying social chemical signaling. Genome Biology and Evolution, 11(10), 2741-2749.

Zhao, H., Xu, D., \& Zhang, S. (2011). Widespread losses of vomeronasal signal transduction in bats. Molecular Biology and Evolution, 28(1), 7-12.

Zhou, Y., \& Rui, L. (2010). Major urinary protein regulation of chemical communication and nutrient metabolism. Vitamins \& Hormones, 83, 151-163. 